\title{
Judicial protection of environmental rights in the Russian Federation: constitutional and legal basis
}

\author{
Elena Vinogradova, Ekaterina Mikhailova, and Maria Mukhlynina* \\ Institute of State and Law of the Russian Academy of Sciences, 10, Znamenka str., Moscow, 119019, Russia
}

\begin{abstract}
The article deals with the problems of determining the nature of environmental rights and the procedure for their protection. The article presents an analysis of the constitutional provisions and norms of the current Russian legislation in the environmental sphere. It is noted that environmental offenses related to the failure of public authorities to fulfil their constitutional and legal obligations in the environmental field should be considered by courts of general jurisdiction according to the rules of administrative proceedings. The idea of creating a system of specialized environmental courts, expressed in science, has been criticized. It is proposed to involve an expert in the case of difficulties in the consideration of cases of environmental violations.
\end{abstract}

\section{Introduction}

The legal capacity of a citizen of the Russian Federation includes the ability to have a wide variety of rights. Their traditional classification is made according to the criterion of the nature of the interest underlying a particular right.

Depending on what interest the right is aimed at, the rights are divided into private and public. This gradation came to us from Roman law. "Law in the objective sense is divided into two broad areas: public law (jus publicum) and civil law (privatum). This division is based on what interests are taken under the protection of legal norms.

There are interests that the entire state, as a whole, considers itself to be the bearer of. The legal norms that govern these interests constitute public law. These norms determine, mainly, the order of the organization and management of the state. On the other hand, there are interests whose bearers are recognized as private individuals.

The totality of legal norms intended to regulate the activities of individuals in relation to these interests is private or civil law. This includes mainly the rules concerning property and family relations. And the state can be the bearer of private rights: the state, like the treasury or the fisk, has property and in its relations with this property is subject to the action of civil law in developed law. As a subject of public law, the state stands above private individuals, and as the owner of civil rights, it stands next to them," V. M. Khvostov wrote [1, p. 4-5].

The difference between private and public rights is also evident in the aspect of their protection: civil (private) cases can be considered both by state courts (general jurisdiction and arbitration) in the order of claim proceedings and by arbitration courts (by mutual agreement of the parties). Public-law conflicts, due to the participation of the State in them, can be resolved only by state courts, in special procedural orderadministrative proceedings or proceedings in cases arising from administrative and other public-law relations in arbitration courts. The transfer of public-law conflicts to arbitration courts is not allowed [2].

Thus, the clarification of the nature of a particular right is not a whim of theorists, but an urgent practical need that explains the mechanisms for the implementation and protection of this right.

The constitutional and legal foundations of judicial protection of environmental rights in the Russian Federation are reflected in the works of Vinogradova E.V., Mikhailova E.V., Bogolyubov E.A., Gate N.A., Minyaeva A.O., Pushkareva E.F., Chalykh I.S., Burkova L.N., Misnik G.A., Mukhlynina M.M., Fomenko V.L., Fitsay D.A. and others. However, a number of issues related to the judicial protection of environmental rights remain insufficiently developed.

\section{Methods}

The methodological basis of the study was based on the following general scientific methods. Methods of analysis, synthesis and deduction formed the basis of this study. The method of factor analysis was used to determine the impact of various factors on the implementation and protection of environmental rights in the Russian Federation.

The informational basis of the study was made up of legal acts, documents of state authorities and their officials, scientific works of Russian scientists on the problems of judicial protection of environmental rights. 


\section{Results and discussion}

Our state provides legal guarantees for the comprehensive development of the individual, safe living on the territory of Russia, and takes measures to preserve the health of its citizens and the well-being of the environment.

According to the amendments made to the Constitution of the Russian Federation in 2020, the Government is obliged to take measures to preserve the natural wealth of Russia, reduce the negative impact of human activities on the environment. In addition, one of the tasks of the Russian state is to create conditions for the education of ecological culture of citizens, responsible attitude to animals.

We can agree with the opinion that the Russian Federation is an ecological state, whose goal is to achieve and maintain a favorable quality of the environment that contributes to the sustainable development of society, the balance of economic and environmental interests of the current and future generations of citizens [3, p. 8].

The following question arises: which subjects are the holders of environmental rights and what is the nature of this right?

The main approach to solving this issue is related to the understanding of environmental rights as the rights of individuals related to ensuring a favorable environment and environmental management. At the same time, environmental rights are considered as the most universal, equally recognized by all legal states $[4, \mathrm{p}$. 17]. In science, the definition of environmental rights is proposed as internationally recognized and constitutionally conditioned measures of possible human behavior in environmental legal relations, adequate to the specifics of their content and structure [5, p. 7].

Also, the environmental rights of a person and a citizen are considered by scientists as the capabilities of an individual recognized by the state and enshrined in legislation, ensuring a sustainable quality of his life and development in interaction with the environment $[6, p$. $10]$.

As you know, any right is implemented within the framework of a legal relationship, the content of which is the corresponding rights and obligations. Based on this, it should be recognized that other entities have environmental responsibilities. Undoubtedly, the first such entity with environmental responsibilities is the state, to which the Russian Constitution has directly assigned them. It is the state, represented by its authorized bodies, that is obliged to take comprehensive measures to protect the environment and ensure the right of citizens of the Russian Federation to live in a favorable environmental environment.

Many researchers recognize the state as the sole bearer of environmental responsibilities. However, this is not the case. The state is the most powerful entity in the field of environmental relations, having not only environmental responsibilities, but also control functions. It is the controlling functions of the State that are aimed at monitoring compliance with environmental legislation by other legal entities.
Every citizen is obliged to take care of the environment and wildlife, and entrepreneurs are obliged to carry out their activities in compliance with the established requirements in the environmental sphere. The existing sanctions in the current domestic legislation for causing harm to the environment are a confirmation of this opinion.

In science, there are two independent legal measures aimed at ensuring the restoration of the environment civil liability for causing environmental damage and payments for negative impact on the environment [7, $\mathrm{p}$. 7-8.]. In addition, the current Russian legislation provides for criminal liability for violations of environmental requirements, the Criminal Code of the Russian Federation combines the norms on liability for environmental crimes in one chapter [8, p. 22].

Thus, all subjects of Russian law are the bearers of environmental obligations, so they are also universal. As it was correctly noted in the literature, the environmental rights of citizens can be violated both by organizations that are direct sources of harm and by the state, which does not cover information about the environmental situation and does not implement environmental programs [9, p. 23-24].

This means that the legal relations in the environmental field can develop between the state and individuals about violations of the constitutional right to reside in the environment and compensation for harm caused to life and health; and between the state and individuals in connection with causing their environmental damage and recovery of sanctions in favor of the state. In addition, citizens can apply to the court with applications for recovery of damage caused by environmental offenses committed by organizations and business entities.

We would like to note separately that at present, the ideas of effective participation in environmental protection activities of entrepreneurs, who are called to be subjects of economic development, on whose efforts the state of natural resources and the course of environmental development largely depend, are actively developing in Russian society. Experts also consider the development of environmental entrepreneurship as a sector of the environmental services market, including certification and support for enterprises engaged in environmental activities [10, p. 75].

Provided that the State is a mandatory participant in disputed legal relations in the environmental sphere, and in these relations it acts as the bearer of supreme power, all legal relations related to violations of environmental rights are public law.

Ensuring the fulfillment of environmental obligations by citizens and legal entities is primarily assigned to them, as well as to the system of federal and other executive authorities as carriers of the ideas of Russian statehood and the core of ensuring environmental safety. The tasks of fulfilling their environmental powers, including duties, are assigned primarily to the executive bodies exercising power on behalf of the people in accordance with Part 2 of Article 3 of the Constitution of the Russian Federation. 
Conflict situations can arise between citizens and public organizations - on the one hand, and public authorities - on the other hand, when the state, its legislative and executive bodies, officials cease to perform their duties, or do not notify the population about the progress of their implementation or the reasons for non-fulfillment, close themselves off from individuals and legal entities, do not interact with them during the legal implementation [10, p. 78-80].

Article 42 of the Constitution of the Russian Federation, in addition to proclaiming the "basic" right to a favorable environment, guarantees every citizen the opportunity to receive reliable information about its condition and to compensate for damage caused to his health or property by an environmental offense. The variety of consequences arising as a result of environmental offenses, the complex structure of environmental damage, as well as specific objects of environmental legal relations determine the need to apply environmental and legal, as well as civil norms to the regulation of public relations [11].

The demands of citizens for damages caused by violation of the constitutional right to reside in the environment can be private if addressed to the subjects of private law and public law, if addressed to the state.

It is interesting that some authors, talking about the protection of environmental rights, distinguish several ways of protecting it. These are judicial protection; appeal to the court of decisions and actions (inaction) of public authorities; compensation by the state for damage caused by illegal actions, decisions or inaction of authorities and appeal to interstate bodies for the protection of violated rights [12, p. 33].

Meanwhile, all of these methods are related to judicial activity. Moreover, no other means of protection, other than the state method of applying to the court, are applicable to environmental rights due to their public legal nature. Arbitration of environmental cases, as well as institutions for the peaceful settlement of legal conflicts in the field of ecology, such as mediation, are unacceptable. This is not in doubt, since the interest underlying environmental rights is public and affects the rights and legitimate interests not only of a particular person who has applied to the court, but also of an indefinite circle of persons.

Other scientists on the basis of analysis of the legislation suggest, in addition to the court, to consider the self-defense of environmental rights and protection of public organizations (public protection environmental rights) [13, pp. 39-40]. Self-defense is an independent remedy provided in article 14 of the Civil code of the Russian Federation and is one of the institutions of criminal law.

The civil-legal meaning of self-defense is not disclosed by the legislator, the law contains only an indication that measures for self-defense of civil rights must be proportionate to the violation of the right. In the criminal legislation, self-defense is provided in two forms - actions in conditions of extreme necessity and necessary defense and is the basis for exemption from criminal liability. In any case, self-defense actions are not enforced, and, in our opinion, they cannot be interpreted as an independent way of protecting rights in the environmental sphere.

As for the activities of public environmental organizations, their importance should not be belittled. In cases where public authorities are inactive, and citizens are not aware of the existence and consequences of environmental violations, it is they who, as civil society bodies, should apply to the court with applications to challenge the actions or inaction of the authorities that violate the environmental rights of citizens to compensate the caused damage. Public organizations can also apply to the Prosecutor's Office with relevant statements.

It can be noted that the number of environmental cases considered by the courts is very small. This is also due to the legal awareness of people - they do not yet perceive their right to live and develop in a favorable environmental environment as one of the fundamental, most important rights in the state system of legal guarantees. But, in addition, it is also important that applicants do not always have a clear understanding of the procedure for protecting environmental rights.

First of all, Part 1 of Article 45 of the Civil Procedure Code of the Russian Federation provides for the right of the prosecutor to apply to a court of general jurisdiction with a statement in defense of the right to a favorable environment. This means that the legislator directly refers cases related to violations of environmental rights to the jurisdiction of the system of courts of general jurisdiction. This also means that these cases must be considered according to the rules of civil proceedings. The legal status of the plaintiff in this case is occupied by the citizen in whose interests the application is filed, or an indefinite circle of persons.

However, in accordance with the provision of Article 17 of the Code of Administrative Procedure of the Russian Federation, cases arising from administrative and other public legal relations related to the exercise of judicial control over the legality and validity of actions, omissions, decisions of public authorities, the exercise of state and other public powers must be considered in the order of administrative proceedings.

According to the Resolution of the Plenum of the Supreme Court of the Russian Federation No. 36 of 27.09.2016 «On certain issues of application by courts of the Code of Administrative Procedure of the Russian Federation», cases arising from legal relations that are not based on equality, autonomy of will and property independence of their participants, in which one of the participants in the legal relationship exercises administrative and other public authority to execute and apply laws and regulations in relation to another participant, are considered in the order of administrative proceedings.

The Plenum stressed that the debate on the recognition of acts of public authorities, of which arise, change or terminate civil matters, void (unlawful) are not subject to review in the manner prescribed by the administrative procedure Code. Thus, public legal acts, decisions and actions (or inaction) addressed to an indefinite circle of persons are challenged in administrative proceedings, and acts of public authorities 
related to the civil status of a particular person are subject to challenge in civil proceedings.

\section{Conclusions}

Summing up, we note that cases in the environmental sphere can be considered both according to the rules of civil proceedings, and within the framework of the administrative procedure. In addition to the fact that the wrong choice of the procedural form of protection of the violated right entails the recognition of the decision as illegal, the consideration of the case according to the rules of administrative proceedings gives citizens significant preferences. In administrative proceedings, the burden of proving the conformity of the contested act with the law is placed on the body that adopted the act, and the procedural activity of the court is much higher than that in civil proceedings.

If the violation of environmental rights of citizens occurred as a result of private law environmental violations by another entity of (failure of the employer, business entity, organization of environmental security), the case for compensation for the specified entity of harm should be considered in civil proceedings under the rules of action proceedings.

If the public authority, local government officials do not comply with the requirements of environmental legislation, as a result violated the constitutional right of a citizen to reside in the environment, demands for the recognition of the relevant unlawful actions (inaction), decisions and other acts should be considered in administrative proceedings. If an act of a public authority is the basis for the emergence, change or termination of the civil rights and obligations of a particular person and at the same time violates his right to live in a favorable environmental environment. The challenge of such acts is carried out according to the rules of civil proceedings.

Some authors note the difficulties associated with the consideration of environmental cases by the courts. For example, they write that "the judicial authorities currently do not exercise active functions for the protection of environmental rights", and in this regard, they propose to create an independent system of environmental courts [14, p. 133].

First of all, the judicial authorities do not initiate cases on their own initiative, and protect the violated rights at the request of the copyright holder or an authorized public authority. Secondly, the procedural order of consideration of environmental cases is not characterized by significant features that would require a narrow specialization of judges.

Finally, in our state, the number of environmental cases is not so large, which is not least due to the steady improvement of environmental legislation and the systematic work of state regulatory and law enforcement agencies.

Therefore, the creation of a separate judicial system for the consideration of environmental cases is impractical. In the event of difficulties in the process of considering an environmental dispute, the court must involve an expert in the case, assigning the corresponding costs later to the losing party.

\section{References}

1. V.M. Khvostov, The history of Roman law: Manual for lectures, Third edition (Moscow, 1907)

2. E.V. Mikhailova, Procedural forms of protection of subjective civil rights, freedoms and legitimate interests in the Russian Federation (judicial and non-judicial) (2017)

3. A.O. Minyaev, Constitutional foundations of environmental law: Abstract of the dissertation for the degree of Doctor of Law (2003)

4. E.F. Pushkareva, International environmental law and order and environmental human rights: Abstract of the dissertation for the degree of Doctor of Law (Moscow, 2008)

5. I.S. Chalykh, Constitutional and legal guarantees of subjective environmental rights: Abstract of the dissertation for the degree of Candidate of Legal Sciences (Belgorod, 2010)

6. L.N. Burkova, Environmental human rights in the Russian Federation (constitutional and legal aspect): Abstract of the dissertation for the degree of Candidate of Legal Sciences (Volgograd, 2005)

7. G.A. Misnik, Compensation of environmental damage in Russian law: Abstract of the dissertation for the degree of Doctor of Law (Moscow, 2008)

8. E.V. Vinogradova, Problems of jurisdictional jurisdiction of crimes encroaching on international environmental safety, Law and modern states, 2-3, 22-26 (2018)

9. N.A. Geit, Protection of environmental human and civil rights in the context of globalization. Development of Russian legislation, Law and modern States, 23-24 (2019)

10. S.A. Bogolyubov, Implementation of environmental policy through law: monograph (Moscow, 2015)

11. M.M. Mukhlynina, Constitutional guarantees of citizens' rights as a condition for sustainable environmental development, E3S Web of Conferences, 208, 06011 (2020). DOI: https://doi.org/10.1051/e3sconf/202020806011

12. V.L. Fomenko, Ways to protect the environmental rights of citizens, Bulletin of Krasnodar University of the Ministry of Internal Affairs of Russia, 4(26), 33-35 (2014)

13. E.A Bogolyubov, Participation of environmental human rights organizations in the judicial protection of environmental rights, Prologue: journal of Law, 4, 38-43 (2017)

14. D.A. Fitzai, Protection of environmental rights: some problems of theory and practice, Journal of Russian Law, 3, 127-135 (2018). 